\title{
Cop Enhancement of Vapour Compression Refrigeration System
}

\author{
B Sairamakrishna, T Gopala Rao, N Rama Krishna
}

\begin{abstract}
This experimental investigation exemplifies the design and testing of diffuser at compressor inlet and nozzle at condenser outlet in vapour compression refrigeration system with the help of R134a refrigerant. The diffuser with divergence angle of $12^{\circ}, 14^{\circ}$ and the nozzle with convergent angle $12^{\circ}, 14^{\circ}$ are designed for same inlet and outlet diameters. Initially diffusers are tested at compressor inlet diffuser is used with inlet diameter equal to exit tube diameter of evaporator and outlet tube diameter is equal to suction tube diameter of the compressor. Diffuser helps to increases the pressure of the refrigerant before entering the compressor it will be helps to reduces the compression work and achieve higher performance of the vapour compression refrigeration system. Then nozzles are testing at condenser outlet, whereas nozzle inlet diameter equal to discharging tube diameter of condenser and outlet diameter equal to inlet diameter of expansion valve. Additional pressure drop in the nozzle helped to achieve higher performance of the vapour compression refrigeration system. The system is analyzes using the first and second laws of thermodynamics, to determine the refrigerating effect, the compressor work input, coefficient of performance (COP).
\end{abstract}

Key words: Diffuser, Nozzle, Coefficient of performance, Refrigeration effect

\section{INTRODUCTION}

In vcr system, the refrigerant under goes phase changes from liquid to vapor and then vapor to liquid in a closed cycle by absorbing the heat in the evaporator and reject the heat at condenser. The coefficient of performance (cop), which is a ratio of heat transfer rate at the evaporator to the power input to the compressor in the refrigeration system. The coefficient of performance can be increased either by decreasing the compressor work or by increasing the refrigeration effect. Different type of methods have been tried out for improving the cop of the vapour compression refrigeration system, as reported in literature.

Manuscript received on April 01, 2021.

Revised Manuscript received on April 15, 2021.

Manuscript published on June 10, 2021.

* Correspondence Author

B Sairamakrishna*, Asst Professor, Department of Mechanical Engineering, Amrita Sai Institute of Science and Technology, Paritala, India. Email ID: Sairamkrishna73@gmail.com

T Gopala Rao, Asst Professor, Department of Mechanical Engineering, Amrita Sai Institute of Science and Technology, Paritala, India. Email ID: gopalarao.t993@gmail.com

N Rama Krishna, Asst Professor, Department of Mechanical Engineering, Amrita Sai Institute of Science and Technology, Paritala, India.Email ID: ramkisrkr126@gmail.com

(c) The Authors. Published by Lattice Science Publication (LSP). This is an open access article under the CC BY-NC-ND license (http://creativecommons.org/licenses/by-nc-nd/4.0/)
G.Naga Raju et al [1] in this paper have studied enhancement of cop of vapour compression refrigeration system by using the diffusers at compressor inlet and as well as condenser inlet.When using the diffuser at compressor inlet the coefficient of performance is increased by $6 \%$ and using the diffuser at condenser inlet the coefficient of performance is increased by $3 \%$.

Neeraj Upadhyay et al [2] to studied the analytical study of vapour compression refrigeration by using diffuser and sub-cooling.to improve the cop of the system either by decreasing the compressor work are increasing the refrigeration effect. In this paper to increasing the refrigeration effect by incorporating of diffuser and sub cooling preoces. By using the diffuser consumption power is by compressor and cop is enhanced from 2.65 to 3.38 .

Vivek Kumar et al [3] have developed a new configuration by inducting 1 . Diffuser in between the condenser inlet and compressor,2. Heat exchanger at condenser outlet. By using these two to evaluate the different parameters like coefficient of performance, refrigerating effect and compressor work of this system with the help of R134a refrigerant. Compared these parameters with convectional system the cop of modified system increased by approximately 1.14 .

P.G.Lohote et al [4] have studied the performance of different condenser by changing the pressure and change in cop of refrigeration system. When changing the convectional condenser by micro channel heat exchanger the pressure changes there are change in rate of heat transfer. This will helps to control the heat losses occurring in the condenser section. So that system of different condenser is gives the batter cop than the convectional system.

Nurul Seraj1 et al [5]In this paper to studied to enhanced the coefficient of performance of vcr system the Initially The Diffuser Of Increasing Cross-Sectional Area Profile Was Designed, Fabricated And Introduced In Our VCR Apparatus. The Size of Diffuser Selected Was Of 15 Degree Divergence Angle. By Using Diffuser Power Consumption Is Less for Same Refrigerating Effect So Performance Is Improved. The Size of The Condenser Can Also Be Reduced Due To More Heat Transfer.

S.Saboor et al [6] to study the experimental analysis of of vapour compression refrigeration system by using the diffuser at condenser inlet concept experimental approach to compensate the compressor work by providing a diffuser at the inlet of the condenser. Diffuser converts the high velocity available at the compressor discharge into the pressure energy.

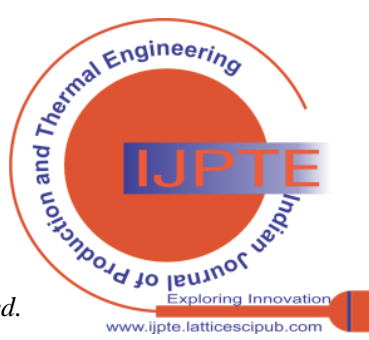


M. Yohan et al.,[7] to studied the use of diffuser in refrigeration system at condenser inlet. The performance can be enhanced by reducing the compressor work by using of diffuser. The system cop was increased by $6 \%$ and work of the compressor was reduced by $6.10 \%$.

P. Pranitha et al.,[8] In this study to analysis the performance of vcr system by placing the nozzle and diffuser. Nozzle is incorporated at inlet of the evaporator and diffuser is incorporated at inlet of the condenser.

Bala Kartheek et al.,[9] In this experiment evaluate the performance of the vapour compression refrigeration system by using the diffuser at condenser inlet and nozzle at inlet of the evaporator. The diffuser reduces the mechanical work required to the refrigerant and nozzle enhance the refrigeration effect by providing an increase in velocity to the refrigerant. By using these two system performance is increased.

B.Sandhya Rani et al.,[10] In this paper study the experiment was successfully completed by incorporate the nozzle in the cycle at outlet of the condenser. The exta pressure droped in the nozzle, these additional help to achieve the more performance of the refrigeration system. The convergent angle of nozzle is increases from $10^{\circ}$ to $14^{\circ}$. The $14^{\circ}$ convergent angle of nozzle is got the better cop of the system.

K.Jaya Sudheer Kumar et al.,[11] to study this paper to evaluate the performance of the vcr system without and with nozzle at inlet of the expansion valve. By using the nozzle in the system again decreasing of refrigerant pressure before entering the evaporator. It improve the refrigeration effect and increase the cop of the system increases.

\section{EXPERIMENTAL SET-UP AND METHODOLOGY}

\section{Manufacturing of diffuser and nozzle :-}

Diffuser is a passive device, it will increases the pressure energy by converting the available kinetic energy at the inlets and the nozzle is a device that transforms the pressure energy into kinetic energy without the assistance of any external work. The flow of the refrigerant in the vapour compression refrigeration system is sub sonic flow. The diffuser and nozzle both can be manufactured with the following dimensions. The diagrams of diffusers as shown below in figure2.

Inlet diameter of entrance $\left(\mathrm{d}_{2}\right)=10 \mathrm{~mm}$

Outlet diameter of entrance $\left(\mathrm{d}_{1}\right)=12 \mathrm{~mm}$

Outlet diameter of exit $\left(\mathrm{D}_{1}\right)=16 \mathrm{~mm}$

Inlet diameter of exit $\left(\mathrm{D}_{2}\right)=14 \mathrm{~mm}$

Angle $(\theta)=12^{\circ}, 14^{\circ}$

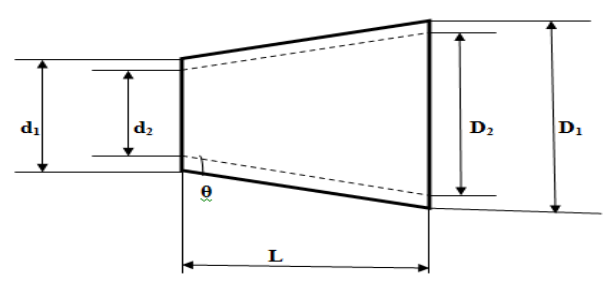

Line diagram of diffuser

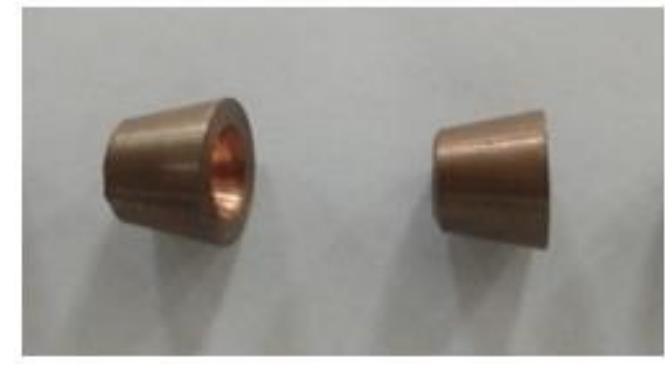

Diffusers

Inlet diameter of entrance $\left(\mathrm{d}_{2}\right)=14 \mathrm{~mm}$

Outlet diameter of entrance $\left(\mathrm{d}_{1}\right)=16 \mathrm{~mm}$

Outlet diameter of exit $\left(D_{1}\right)=12 \mathrm{~mm}$

Inlet diameter of exit $\left(D_{2}\right)=10 \mathrm{~mm}$

Angle $(\theta)=12^{\circ}, 14^{\circ}$

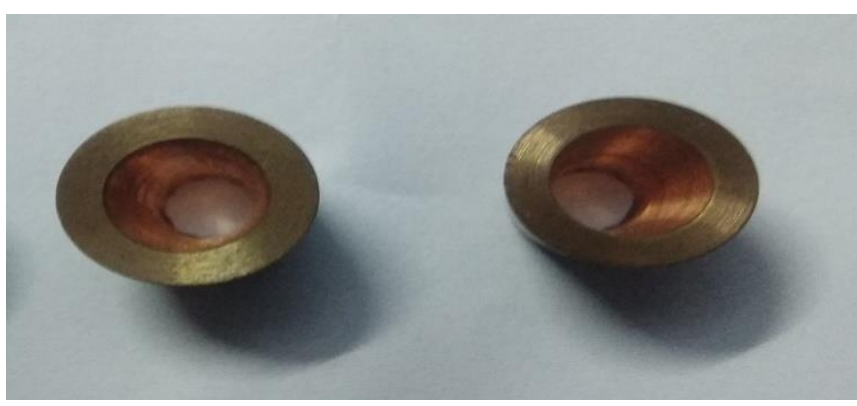

\section{Experimental set up with diffuser at compressor inlet :-}

It mainly consists of the main loop of system. The main loop is consists of a compressor, condenser, capillary tube valve (expansion valve) and evaporator. The compressor used in this one is hermetically sealed reciprocating type compressor and capacity is $1 / 8^{\text {th }}$ TOR. The condenser and evaporator both are the coppered single tube. In this single flow tube condenser, inner side refrigerant flows and air is flows out side of the tube. The refrigerant then flows in to the evaporateor through expansion valve. The capillary tube is used to control the flow rate of the refrigerant in to the evaporator coil and also to set the difference pressure. In the one flow tube evaporator, the refrigerant flow through the inner side of the tube and water is in storage tank outside of the tubes. To minimize the heat losses, the tube is insulated. The four diffusers were tested at compressor inlet by changing one by one diffuser.

The readings were taken with changing the diffuser at compressor inlet. By using the five pressure gauges, these gauges are incorporated in the system to note down the pressure at various points ( diffuser inlet, outlet, compressor outlet, condenser outlet and inlet of evaporator). By using the temperature sensors, to measure the temperatures at various points in the system like as pressure guages. The voltage and the current in the system are measured by using the voltmeter and ammeter. Power consumption of the syatem is constant that is 230 wats.

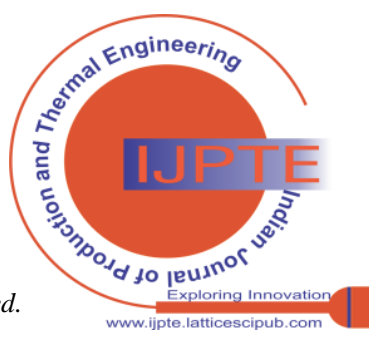




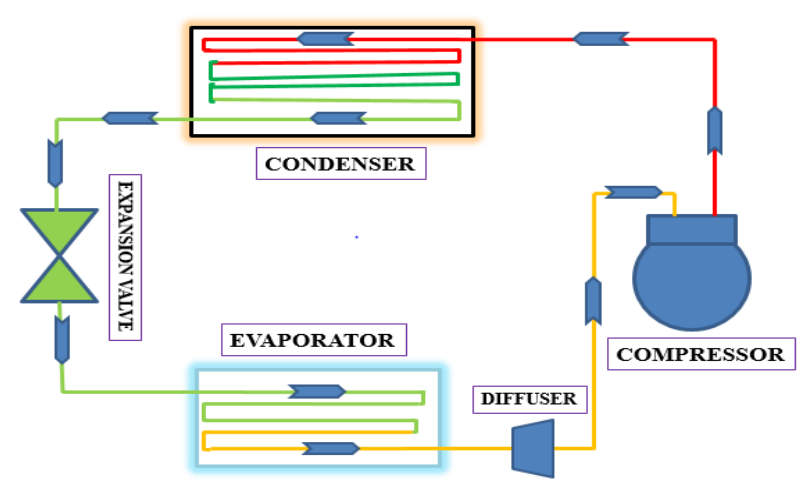

Line diagram of diffuser at compressor

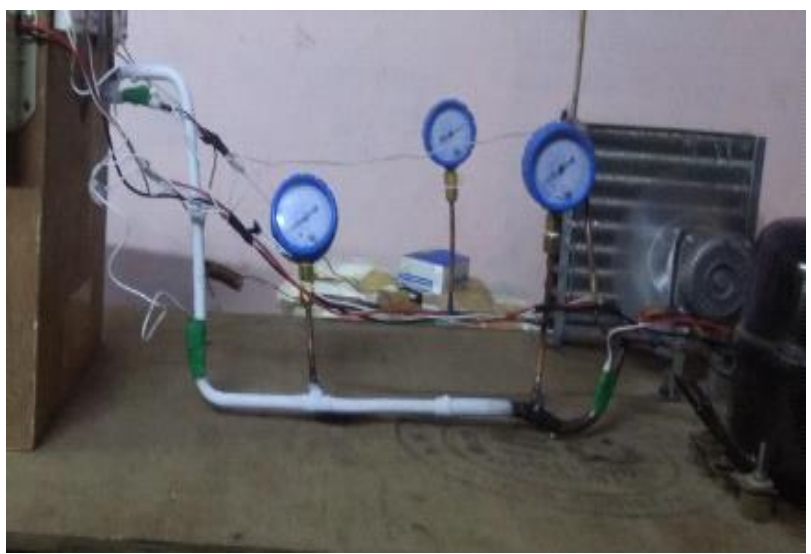

Experimental set up

Experimental set up with nozzle at condenser outlet :-

The schematic diagram of vapour compression refrigeration system with diffuser at expansion valve inlet shown in figure below. In above set-up one of the diffuser $\left(14^{\circ}\right)$ gives the maximum cop, it will fixed at compressor inlet. Now again testing the nozzle at expansion valve inlet same as above. Initially experiment carried without nozzle and readings are noted. Then experiment will repeated with nozzle the readings (pressure \& temperature) are noted. Nozzle at expansion valve, is to reduce the pressure coming from the condenser without any work input.

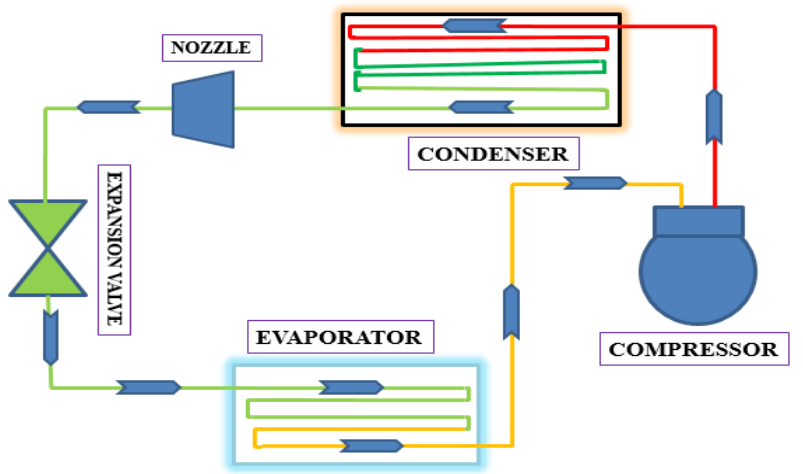

Line diagram with nozzle at expansion valve inlet

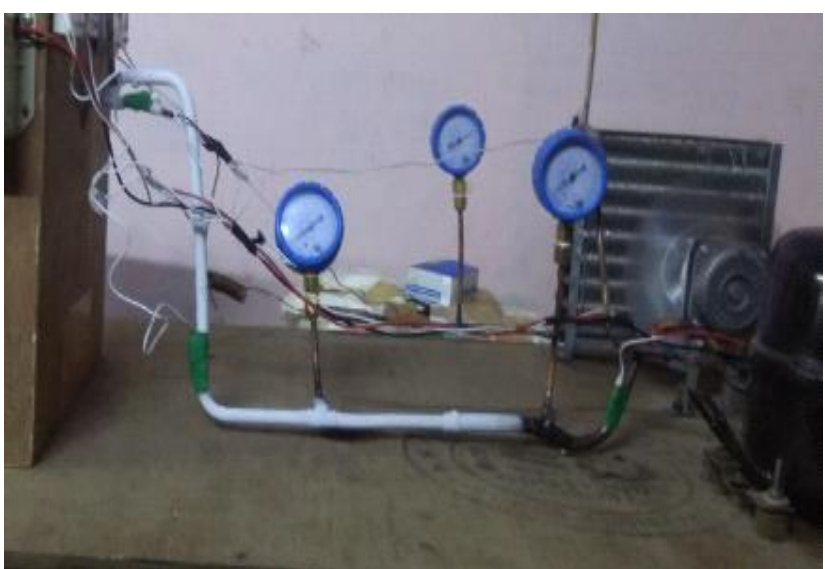

Experimental set up

\section{RESULTS AND DISCUSSION}

Experimental Results with and without diffusers at compressor inlet :-

\begin{tabular}{|c|c|c|c|c|c|c|}
\hline \multirow{3}{*}{ Position } & \multicolumn{3}{|c|}{ Pressure } & \multicolumn{3}{|c|}{ Temperature } \\
\hline & \multirow{2}{*}{$\begin{array}{c}\text { With } \\
\text { out } \\
\text { Diffu } \\
\text { ser }\end{array}$} & \multicolumn{2}{|c|}{$\begin{array}{c}\text { With } \\
\text { Diffuser }\end{array}$} & \multirow{2}{*}{$\begin{array}{c}\text { With } \\
\text { out } \\
\text { Diffu } \\
\text { se }\end{array}$} & \multicolumn{2}{|c|}{$\begin{array}{c}\text { With } \\
\text { Diffuser }\end{array}$} \\
\hline & & $12^{0}$ & $14^{0}$ & & $12^{0}$ & $\begin{array}{c}14 \\
0\end{array}$ \\
\hline $\begin{array}{c}\text { Compresso } \\
\text { r inlet }\end{array}$ & 0.41 & 0.85 & 1.3 & 32 & 36 & 39 \\
\hline $\begin{array}{l}\text { Condenser } \\
\text { inlet }\end{array}$ & $\begin{array}{c}11.8 \\
0\end{array}$ & 11.80 & $\begin{array}{c}11.8 \\
0\end{array}$ & 43 & 43 & 43 \\
\hline $\begin{array}{c}\text { Condenser } \\
\text { outlet }\end{array}$ & $\begin{array}{c}11.8 \\
0\end{array}$ & 11.80 & $\begin{array}{c}11.8 \\
0\end{array}$ & 33 & 33 & 33 \\
\hline $\begin{array}{l}\text { Evaporator } \\
\text { Inlet }\end{array}$ & 0.41 & 0.41 & 0.41 & 2.3 & 2.3 & $\begin{array}{l}2 . \\
3\end{array}$ \\
\hline
\end{tabular}

From $\mathbf{p}$-h chart of $\mathbf{R 1 3 4 a}$

$\mathrm{h} 1=430 \mathrm{kj} / \mathrm{kg}$

$\mathrm{h} 1^{\prime}=439 \mathrm{kj} / \mathrm{kg}$

$\mathrm{h} 2=510 \mathrm{kj} / \mathrm{kg}$

$\mathrm{h} 3=\mathrm{h} 4=\mathrm{hf} 3=250 \mathrm{kj} / \mathrm{kg}$

Compressor work (W.D) $=\mathrm{h} 2-\mathrm{h} 1=510-430$

$$
=80 \mathrm{kj} / \mathrm{kg}
$$

Refrigeration effect $=\mathrm{h} 1-\mathrm{h} 4=430-250$

$$
=180 \mathrm{kj} / \mathrm{kg}
$$

Diffuser work $=\mathrm{h} 1$ ' $-\mathrm{h} 1=439-430$

$$
=9 \mathrm{kj} / \mathrm{kg}
$$

Reduction in compressor work $=(\mathrm{h} 2-\mathrm{h} 1)-(\mathrm{h} 1$ ' $-\mathrm{h} 1)$

$$
=80-9
$$

$$
=79 \mathrm{kj} / \mathrm{kg}
$$

COP without diffuser $=\frac{\text { Refrigeration } \text { effect }}{\text { Compressor } \text { work }}$

$$
=180 / 80
$$

$$
=2.25
$$

COP with diffuser $=\frac{\text { Refrigeration effect }}{\text { Reduction } \text { in compressor } \text { work }}$

$$
=180 / 71
$$$$
=2.53
$$

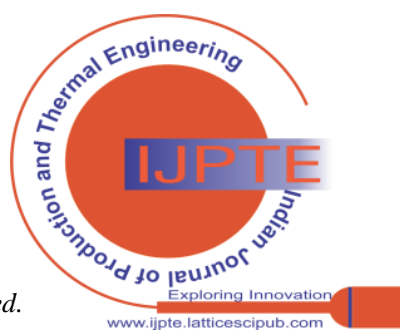




\begin{tabular}{|c|c|c|c|c|}
\hline \multicolumn{2}{|c|}{ parameters $\rightarrow$} & $\begin{array}{l}\text { Refrigeration } \\
\text { work } \\
(\mathbf{k j} / \mathbf{k g}) \\
\end{array}$ & $\begin{array}{l}\text { Reduction } \\
\text { in } \\
\text { compressor } \\
\text { work(kj/kg) }\end{array}$ & COP \\
\hline \multicolumn{2}{|c|}{ Without diffuser } & 180 & 80 & 2.25 \\
\hline \multirow[b]{2}{*}{$\begin{array}{l}\text { With } \\
\text { diffuser }\end{array}$} & 120 & 180 & 75 & 2.4 \\
\hline & 140 & 180 & 71 & 2.53 \\
\hline
\end{tabular}

\section{Pressure vs diffuser divergence angles: -}

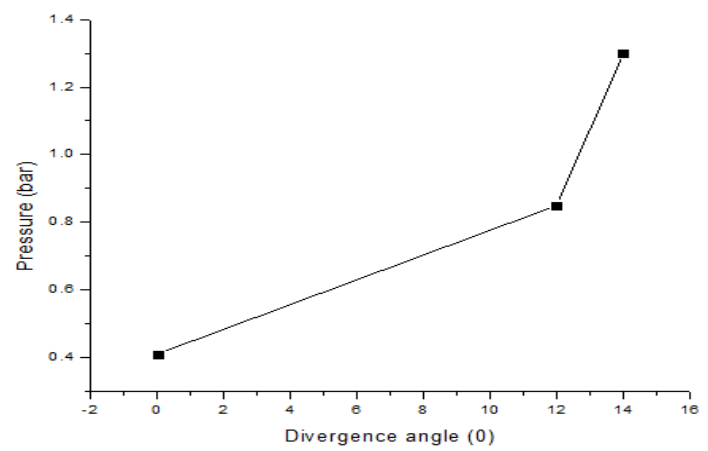

Variation of pressure with respect to divergence angles

The above diagram shows the variation of pressure of a refrigerant with respect to the diffuser divergence angle. Initially the experiment was carried out without a diffuser. The pressure is 0.41 bar when $12^{0}$ divergence angle of diffuser is placed at compressor inlet the pressure was increased to 0.85 bar. Then $14^{0}$ divergance angle diffuser is placed the pressure increased to 1.3 bars. This is the maximum pressure when we are using diffuser. The diffuser into pressure energy according to the first law of the thermodynamics.

Temperature vs diffuser divergence angles:-

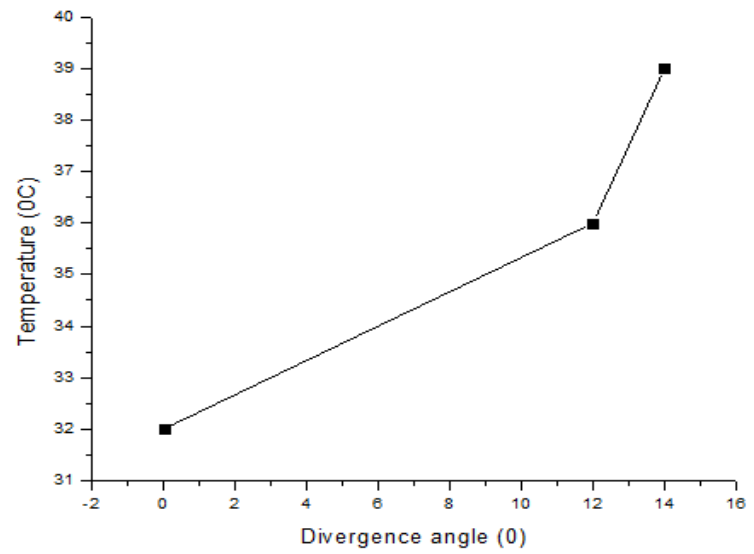

Variation of Temperature with respect to divergence angles

The above figure shows the variation of the temperature with respect to changing of diffuser divergence angles. Initially the temperature at $32^{0}$ without a diffuser. Then the temperature of the refrigerant is increased from $36^{\circ} \mathrm{C}$ to $39^{\circ} \mathrm{C}$ when there are using the diffusers. The maximum temperature is $39^{\circ} \mathrm{C}$ is obtained when we are using the diffuser of (divergence) $14^{0}$ this is the maximum temperature.

\begin{tabular}{|c|c|c|c|c|c|c|}
\hline \multirow[b]{3}{*}{ Position } & \multicolumn{3}{|c|}{ Pressure } & \multicolumn{3}{|c|}{ Temperature } \\
\hline & \multirow{2}{*}{$\begin{array}{c}\text { Withou } \\
t \\
\text { Nozzle }\end{array}$} & \multicolumn{2}{|c|}{$\begin{array}{l}\text { With } \\
\text { Nozzle }\end{array}$} & \multirow{2}{*}{$\begin{array}{c}\text { Withou } \\
t \\
\text { Nozzle }\end{array}$} & \multicolumn{2}{|c|}{ Nozzle } \\
\hline & & 120 & 140 & & 120 & 140 \\
\hline $\begin{array}{c}\text { Compresso } \\
\text { r inlet }\end{array}$ & 0.39 & $\begin{array}{c}0.3 \\
9\end{array}$ & $\begin{array}{c}0.3 \\
9\end{array}$ & 30.5 & $\begin{array}{c}30 . \\
5\end{array}$ & $\begin{array}{c}30 . \\
5\end{array}$ \\
\hline $\begin{array}{c}\text { Condenser } \\
\text { inlet }\end{array}$ & 11.65 & $\begin{array}{c}11 . \\
8\end{array}$ & $\begin{array}{c}11 . \\
8\end{array}$ & 40.2 & $\begin{array}{c}40 . \\
5\end{array}$ & $\begin{array}{c}40 . \\
5\end{array}$ \\
\hline $\begin{array}{c}\text { Condenser } \\
\text { outlet } \\
\text { (Nozzle } \\
\text { outlet) }\end{array}$ & 11 & $\begin{array}{c}10 . \\
6\end{array}$ & $\begin{array}{c}10 . \\
2\end{array}$ & 30.2 & 25 & 23 \\
\hline $\begin{array}{l}\text { Evaporator } \\
\text { Inlet }\end{array}$ & 0.39 & $\begin{array}{c}0.3 \\
6\end{array}$ & 0.3 & 2.3 & 2.3 & 2.3 \\
\hline
\end{tabular}

COP vs diffuser divergence angles:-

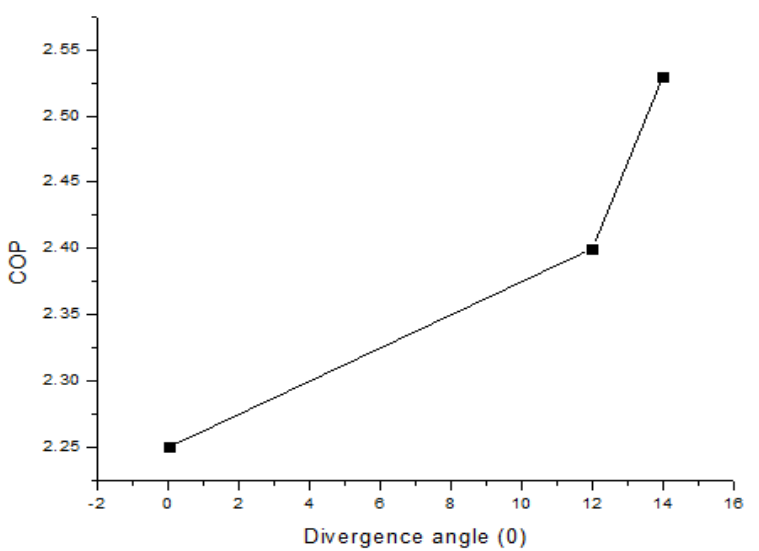

Variation of COP with respect to divergence angles

The figure represents the effect of diffuser on co-efficient of performance in vapour compression refrigeration system. It was noted that the maximum percentage of reduction in compressor work and maximum percentage of coefficient of performance (COP) are obtained when we are using the $14^{0}$ divergence angle of diffuser the COP also increases when using $12^{\circ}$ but maximum COP was obtained at $14^{0}$ diffuser. By applying first and second law of thermodynamics. To the diffuser, it was observed that the increase in enthalpy is proportional to the kinetic energy of refrigerant. The rise in enthalpy was without any power consumption.

\section{Experimental Results with and without nozzles at condenser outlet :-}

The line diagram vapour compression refrigeration system with nozzle at condenser outlet is shown above. In the above set up (Experiment with diffuser) one of the diffuser is given batter cop then the other one it will be fixed in the system and then experiment will repeat with nozzles at condenser outlet. In this one nozzle gives the batter performance.

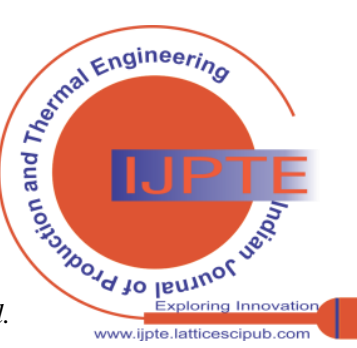




\section{Calculations for $14^{0}$ Nozzle}

From p-h chart of R134a

$\mathrm{h} 1=418 \mathrm{kj} / \mathrm{kg}$

$\mathrm{h} 2=492 \mathrm{kj} / \mathrm{kg}$

$\mathrm{h} 3=\mathrm{h} 4=\mathrm{hf} 3=244 \mathrm{kj} / \mathrm{kg}$

Compressor work (W.D) = h2 - h1 = $492-418$

$$
=74 \mathrm{kj} / \mathrm{kg}
$$

Refrigeration effect $=\mathrm{h} 1-\mathrm{h} 4=418-244$ $=174 \mathrm{kj} / \mathrm{kg}$

COP with diffuser $=\frac{\text { Refrigeration effect }}{\text { Compressor } \text { wprk }}$
$=174 / 74$
$=2.35$

\begin{tabular}{|l|c|c|c|c|}
\hline \multicolumn{2}{|l|}{$\begin{array}{l}\text { parameters } \\
\rightarrow\end{array}$} & $\begin{array}{l}\text { Refrigeration } \\
\text { work } \\
(\mathbf{k j} / \mathbf{k g})\end{array}$ & $\begin{array}{l}\text { Reduction } \\
\text { in } \\
\text { compressor } \\
\text { work(kj/kg) }\end{array}$ & COP \\
\hline $\begin{array}{l}\text { Without } \\
\text { diffuser }\end{array}$ & 180 & 80 & 2.25 \\
\hline $\begin{array}{l}\text { With } \\
\text { diffuser }\end{array}$ & 120 & 180 & 75 & 2.33 \\
\cline { 2 - 5 } & 140 & 180 & 71 & 2.35 \\
\hline
\end{tabular}

Pressure vs nozzle converging angles: -

The above diagram shows the variation of pressure of a refrigerant with respect to the nozzle converging angle. Initially the experiment was carried out without a nozzle. The pressure is 11.00 bar when $12^{0}$ converging angle of nozzle is placed at compressor inlet the pressure was decreased to 10.60 bar. Then $14^{0}$ converging angle nozzle is placed the pressure decreased to 10.20 bars. This is the maximum pressure reduction when we are using nozzle.

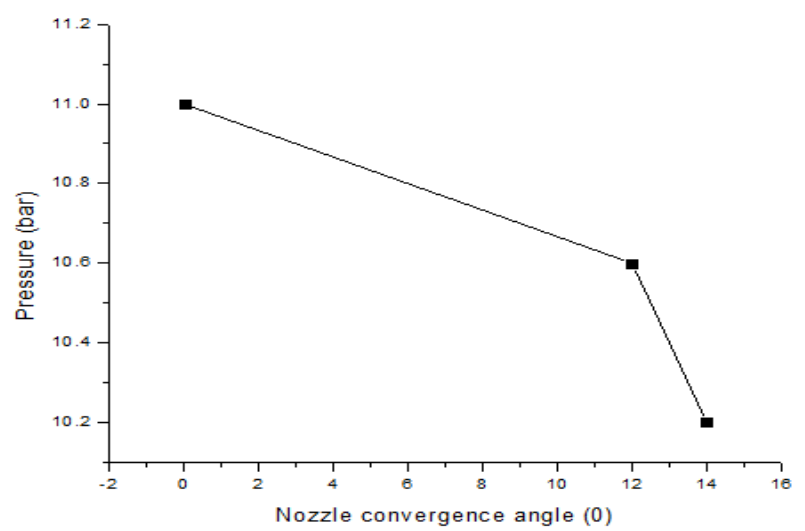

Variation of pressure with respect to converging angles

\section{Temperature vs nozzle converging angles:-}

The above figure shows the variation of the temperature with respect to changing of nozzle converging angles. Initially the temperature at $30.2^{0}$ without a nozzle. Then the temperature of the refrigerant is decreased from $25^{\circ} \mathrm{C}$ to $23^{\circ} \mathrm{C}$ when we are using the nozzles. The maximum temperature reduction is $34.2^{0} \mathrm{C}$ is obtained when we are using the nozzle of (converging) $14^{0}$ temperature.

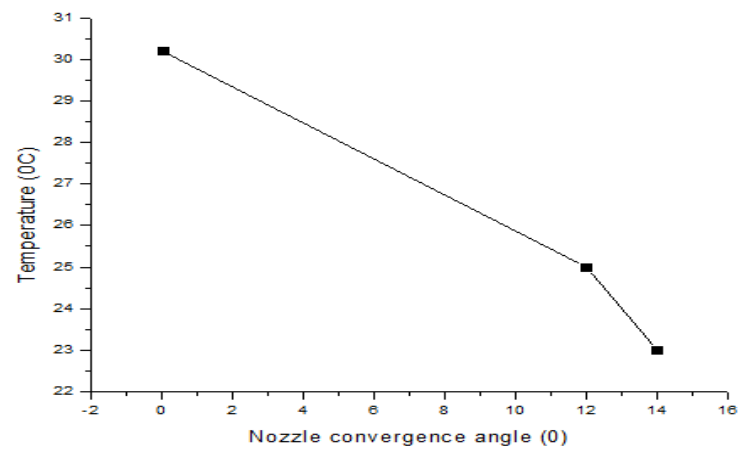

Variation of temperature with respect to converging angles

\section{COP vs nozzle converging angles:-}

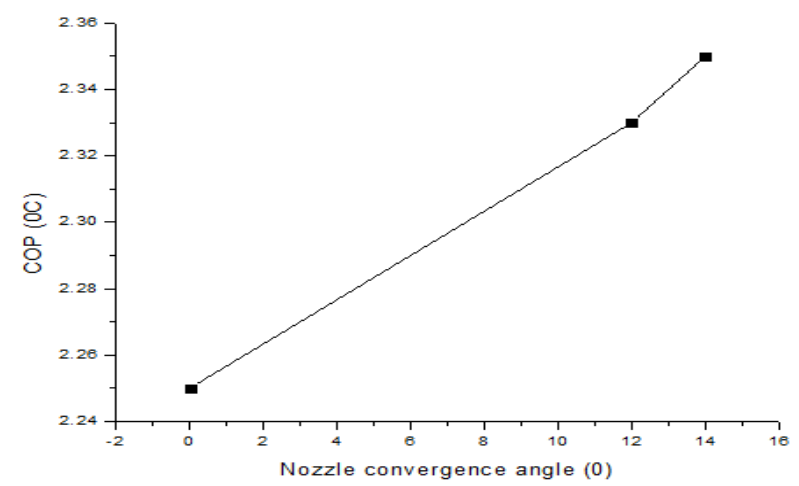

Variation of COP with respect to converging angles

The figure represents the effect of diffuser on co-efficient of performance in vapour compression refrigeration system. It was noted that the maximum percentage of reduction in compressor work and maximum percentage of coefficient of performance (COP) are obtained when we are using the $14^{0}$ converging angle of nozzle the COP also increases when using $12^{0}$ but maximum COP was obtained at $14^{0}$ nozzle. By applying first and second law of thermodynamics. To the nozzle, it was observed that the increase in enthalpy is proportional to the kinetic energy of refrigerant. The rise in enthalpy was without any power consumption.

\section{CONCLUSION}

Experimental investigation has been carried out to study the effect of diffusers at compressor inlet and nozzles at condenser outlet in vapour compression refrigeration system. The two diffusers and two nozzles are tested with divergence angles of $12^{\circ}, 14^{\circ}$.

1. Diffuser at compressor inlet, Both the diffusers were given the better performance of the system (i.e2.40,2.53), but diffuser with divergence angle of $14^{\circ}$ is given the maximum cop (2.53) as compared with other diffuser. Percentage of increase in COP is approximately $6.66 \%$ when we are using the $12^{\circ}$ diffuser and, $12.44 \%$ increases by using the $14^{\circ}$ diffuser. Reduction in compressor work $6.25 \%$ by using $12^{\circ}$ diffuser and $11.25 \%$ by using $14^{\circ}$ diffuser.

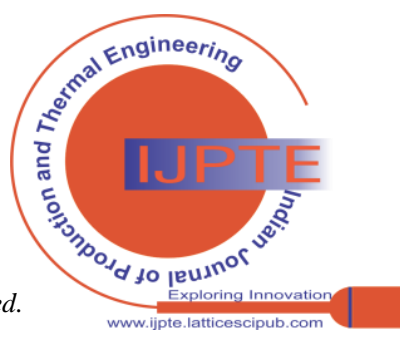


2. Nozzle at condenser outlet, Both the nozzles given batter performance (i.e2.33,2.35) but $14^{\circ}$ nozzle given the maximum cop (2.35) as compared with other nozzle. Percentage of increase in COP is approximately $3.55 \%$ when we are using the $12^{\circ}$ diffuser and, $4.45 \%$ increases by using the $14^{\circ}$ diffuser. Reduction in compressor work $6.25 \%$ by using $12^{\circ}$ diffuser and $11.25 \%$ by using $14^{\circ}$ diffuser.

\section{REFERENCES}

1. G.NAGA ARAJU et al International Journal of Recent Technology and Engineering (IJRTE) ISSN: 2277-3878, Volume-8 Issue-2, July 2019.

2. NeerajUpadhyay IOSR Journal of Mechanical and Civil Engineering (IOSR-JMCE) e-ISSN: 2278-1684,p-ISSN: 2320-334X, Volume 11, Issue 3 Ver. VII (May- Jun. 2014), PP 92-97 www.iosrjournals.org.

3. 3. Vivek Kumar, S.C. Roy International Journal for Research in Engineering Application \& Management (IJREAM) ISSN : 2454-9150 Vol-04, Issue-07, Oct 2018.

4. P.G. Lohote, Dr.K.P. Kolhe, Journal of Emerging Technologies and Innovative Research (JETIR) April 2016, Volume 3, Issue 4, JETIR (ISSN-2349-5162).

5. Nurul Seraj1, Dr. S. C. Roy, International Journal for Research in Applied Science \& Engineering Technology (IJRASET) Volume 5 Issue VI, June 2017 IC Value: 45.98 ISSN: 2321-9653.

6. S.Saboor, M.Yohan, G.Kiran Kumar Proc. of the 5th International Conference on Advances in Mechanical Engineering (ICAME-2011), June 06-08, 2011 S.V. National Institute of Technology, Surat - 395 007, Gujarat, India.

7. M. Yohan and G. kiran Kumar, Proc. of International Conference on Advances in Mechanical Engineering, June 06-08, 2011 S.V. National Institute of Technology, Surat - 395 007, Gujarat, India.

8. P. Pranitha, International Journal of Technical Innovation in Modern Engineering \& Science (IJTIMES) Impact Factor: 3.45 (SJIF-2015), e-ISSN: 2455-2585 Volume 3, Issue 10, October-2017

9. Bala Kartheek, International Journal of Recent Technology and Engineering (IJRTE) ISSN: 2277-3878, Volume-8 Issue-2, July 2019

10. B. Sandhya Rani, International Journal of Mechanical Engineering and Technology.Volume 7, Issue 6, November-December 2016, pp.642-659, Article ID: IJMET_07_06_064 ISSN Print: 0976-6340 and ISSN Online: 0976-6359.

11. K. Jaya Sudheer Kumar, International Journal of Technical Innovation in Modern Engineering \& Science. (SJIF-2017), e-ISSN: 2455-2585 Volume 4, Issue 12, December-2018.

\section{AUTHORS PROFILE}

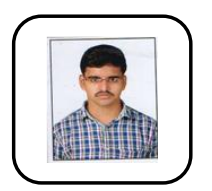

B Sairamakrishna, Asst Professor, Department of Mechanical Engineering, Amrita Sai Institute of Science and Technology, Paritala, India.

Email ID: Sairamkrishna73@gmail.com

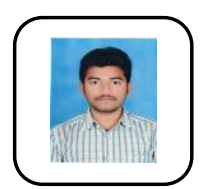

T Gopala Rao, Asst Professor, Department of Mechanical Engineering, Amrita Sai Institute of Science and Technology, Paritala, India.

Email ID: gopalarao.t993@gmail.com

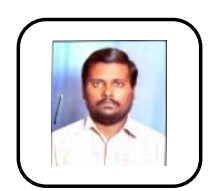

N Rama Krishna, Asst Professor, Department of Mechanical Engineering, Amrita Sai Institute of Science and Technology, Paritala, India.

Email ID: ramkisrkr126@gmail.com 